\section{X-ray imaging and digital processing application in non-destructive assessing of melon seed quality}

\author{
André Dantas de Medeiros ${ }^{1 *} \mathbb{D}$, Maycon Silva Martins ${ }^{1} \mathbb{D}$, Laércio Junio \\ da Silva ${ }^{1}{ }^{(\mathbb{D}}$, Márcio Dias Pereira ${ }^{2}$, Manuel Jesús Zavala León ${ }^{1}{ }^{(i D}$, Denise \\ Cunha Fernandes dos Santos Dias ${ }^{1}$
}

ABSTRACT: Non-destructive and high throughput methods have been developed for seed quality evaluation. The aim of this study was to relate parameters obtained from the free and automated analysis of digital radiographs of hybrid melons' seeds to their seeds' physiological potential. Seeds of three hybrid melon (Cucumis melo L.) cultivars from commercial lot samples were used. Radiographic images of the seeds were obtained, from which area, perimeter, circularity, relative density, integrated density and seed filling measurements were generated by means of a macro (PhenoXray) developed for ImageJ software. After the X-ray test, seed samples were submitted to the germination test, from which variables related to the physiological quality of the seeds were obtained. Variability between lots was observed for both physical and physiological characteristics. Results showed that the use of the PhenoXray macro allows largescale phenotyping of seed radiographs in a simple, fast, consistent and completely free way. The methodology is efficient in obtaining morphometric and tissue integrity data of melon seeds and the generated parameters are closely related to physiological attributes of seed quality.

Index terms: automated image analysis, Cucumis melo L., seed radiography, relative density.

\section{Aplicação do teste de raios- $X$ e processamento digital na avaliação não-destrutiva da qualidade de sementes de melão}

RESUMO: Métodos não-destrutivos e de alto desempenho têm sido desenvolvidos para avaliação da qualidade de sementes. $\mathrm{O}$ objetivo deste estudo foi relacionar parâmetros obtidos a partir da análise gratuita e automatizada de radiografias digitais de sementes de melão híbrido com o seu potencial fisiológico. Foram utilizadas amostras de sementes comerciais de três cultivares híbridas de melão (Cucumis melo L.), cada uma representada por três lotes. Foram obtidas imagens radiográficas das sementes, das quais foram geradas determinações de área, perímetro, circularidade, densidade relativa, densidade integrada e preenchimento da cavidade interna de sementes, por meio de uma macro (PhenoxXray) desenvolvida para o software Image $J^{\circ}$. Após o teste de raios- $X$, as sementes foram submetidas ao teste de germinação, a partir do qual foram obtidas variáveis relacionadas à qualidade fisiológica. Observou-se variabilidade entre lotes para as características físicas e fisiológicas. Os resultados demonstraram que o uso da macro PhenoXray permite a fenotipagem em larga escala das radiografias de sementes de maneira simples, rápida, consistente e totalmente gratuita. A metodologia é eficiente na obtenção de dados morfométricos e de integridade tecidual em sementes de melão, e os parâmetros gerados apresentam estreita relação com atributos fisiológicos da qualidade das sementes.

Termos para indexação: análise automática de imagens, Cucumis melo L., radiografia de sementes, densidade relativa.
Journal of Seed Science, v.42, e202042005, 2020

http://dx.doi.org/10.1590/2317$1545 v 42229761$
$*$ Corresponding author
E-mail: medeiros.seeds@gmail.com

Received: 10/9/2019. Accepted: $1 / 8 / 2020$.

${ }^{1}$ Departamento de Agronomia, Universidade Federal de Viçosa, 36570-900 - Viçosa, MG, Brasil.

${ }^{2}$ Departamento de Agropecuária, Universidade Federal do Rio Grande do Norte, 59280-000 Macaíba, RN, Brasil. 


\section{INTRODUCTION}

The introduction of modern and high-performance techniques capable of generating consistent and fast results, less subjectively and non-destructively, presents great potential for the safe evaluation of the quality of agricultural products (Mahajan et al., 2015).

Among the techniques that reach this proposal is the analysis based on electromagnetic X-ray radiation. This technique, predominantly used in medical applications, has been used in several areas, including seed quality inspection (Rahman and Cho, 2016). However, the visual analysis of the radiographic images is time-consuming and can generate reading errors due to subjective interpretations (Medeiros et al., 2018). The current challenge is to develop methods capable to produce relevant information from the radiographs of seeds, on a large scale in a fast and consistent manner.

Recent advances in the field of computer-aided digital image processing have contributed to making feasible this type of approach. Public domain software such as Image $J^{\bullet}$ has provided promising perspectives to address this purpose and provide automation of analyses related to seed radiographs.

Image $^{\bullet}$ is presented as the world's fastest imaging software (Miart et al., 2018; Schindelin et al., 2012). Semi-automated applications with the use of this software in the analysis of radiographic images of seeds has demonstrated potential for seed analysis (Abud et al., 2018; Medeiros et al., 2018). However, while this type of analysis allows for greater interaction and autonomy of the analyst in the adjustments, it makes the process slow, time-consuming, and often compromises the standardization of analyses on a large scale. Recently, a macro for Image $J^{\circ}$, called PhenoXray (Medeiros et al., 2019), was developed. This macro allowed large-scale phenotyping of brachiaria grass seeds radiographs, obtaining parameters related to their physiological quality.

The application of these technologies to high value-added seeds, such as hybrid melons, could be of interest to the seed industry, since it allows the evaluation of seed quality in a non-destructive, fast and standardized way. Also, it would be an alternative to be used in quality control programs during seed production, being important for the decision making regarding the approval or disposal of seed lots, which would mean saving time and resources.

Considering that the rapid technological development indicates greater opportunities for X-ray inspection in the agricultural sector, especially in seed technology, this research had the aim to relate parameters obtained from the free and automated analysis of digital radiographs of hybrid melons' seeds to their physiological potential.

\section{MATERIAL AND METHODS}

\section{Plant material}

Seeds of three hybrids of melon were used, Bazuca F1 (American cantaloupe, lots 1 to 10), Goldex F1 (Yellow, lots 11 to 20), and Pampa F1 (Italian cantaloupe, lots 21 to 30), from lot samples from the 2017 crop season, each represented by ten seed lots. The seeds were submitted to the following analyses:

\section{Physical analyses}

Seed water content: the seeds were initially submitted to the determination of the water content by the oven method at $105 \pm 3^{\circ} \mathrm{C}$ for 24 hours, based on the Rules for Seed Testing (Brasil, 2009); for this purpose, two subsamples of $5 \mathrm{~g}$ of seeds were used for each lot. Results were expressed as a percentage (wet basis).

X-ray test: for the analysis of the internal morphology of the seeds, five replicates of twenty seeds each of each lot were used. Seed samples were positioned with the embryonic axis facing down and adhesive-tape fixed in an orderly manner on adhesive paper, to allow subsequent individual identification in the posterior analyses. Seeds were then placed inside the Faxitron digital X-ray equipment, model MX-20 (Faxitron X-ray Corp. Wheeling, IL, U.S.A). To generate the radiographic images, the equipment was configured with the radiation exposure time of ten seconds, $23 \mathrm{kV}$ voltage, $41.6 \mathrm{~cm}$ focal length and contrast of the calibrated image in 16383 (width) x 3124 (center). The digital images generated 
were saved in computer in TIFF format, following their processing and analysis.

Automated analysis of the radiographs: for the automated image analysis, the PhenoXray macro (https://sites. google.com/ufv.br/phenoxray) (Medeiros et al., 2019) developed for ImageJ software was used. The macro was developed to process images automatically, being necessary only to indicate the folder containing all the images, properly identified (lot and replication), in the ImageJ ${ }^{\circ}$ software. The analysis started with the segmentation of the images using the Image $J^{\circ}$ Threshold mode. The threshold was automatically set using Yen's automatic multilevel thresholding method to segment the images in the regions corresponding to the melon seeds. The regions of interest were then analyzed from the analyze particles command, which integrates the software Image $J^{\circ}$. Only particles with a surface area between 594 and 2.376 pixels $^{2}$ were considered, which was efficient to select the areas corresponding to the seeds and to ignore areas of noises in the images.

The parameters obtained from the images were: area - selection area obtained in square pixels, and later converted into units of square millimeters $\left(\mathrm{mm}^{2}\right)$; perimeter - the length in millimeters of the outer limit of the selection; circularity - obtained by the equation: $\mathrm{C}=4 \pi * \frac{\text { area }}{\text { (perimeter) }^{2}}$; relative density (average gray)-defined as the sum of the gray values of all pixels in the selected area divided by the number of pixels in the selection, expressed in gray.pixel ${ }^{-1}$; integrated density - the sum of the pixel values in the image or selection, that is equivalent to the product of area and relative density, expressed in gray. $\mathrm{mm}^{2}$. pixel ${ }^{-1}$; filling - percentage of seed area effectively filled by high density material.

After, the images were processed and the measurement results were automatically saved to a TXT file. In addition, files in the JPEG format corresponding to the images' analysis were created in the same directory, which allowed to check the performance of the macro in the processing of the images.

\section{Physiological analysis}

Germination test: conducted on rolls of paper towel for germination humidified with water equivalent to 2.5 times the dry paper mass and kept in a germinator at a constant temperature of $25^{\circ} \mathrm{C}$ (Brasil, 2009). The same seeds submitted to the X-ray test were used, maintaining the same seed arrangement originally used in the previous test. Daily counts of the number of seeds exhibiting primary root protrusion and germinated seeds (normal seedlings) were carried out until the eighth day after sowing. From these data, the speed of germination index (GSI), the speed of primary root protrusion (RPS) and the synchrony were calculated, according to the formulas described in Silva et al. (2019). All the variables obtained based on the germination test were calculated using the Germcalc function, contained in the package SeedCalc of the R software.

Seedling analysis: after the final count of the germination test, the seedlings and non-germinated seeds of each replicate were scanned, and the generated images were evaluated in ImageJ software. The images were used to measure the length of the shoot and the primary root of the seedlings, expressed in $\mathrm{mm}$.seedling $^{-1}$. The length data were processed with the package SeedCalc of the R software, through the Plantcalc function, and the parameters were calculated: seedling total length and uniformity indexes, vigor and corrected vigor.

\section{Experimental design and statistical analysis}

The experiment was conducted in a completely randomized experimental design, with four replications. Data were submitted to analysis of variance (ANOVA). After confirming the normal distribution of errors by the Shapiro-Wilk test and the homogeneity of variances by the Bartlett test, the averages were grouped by the Scott-Knott test $(p \leq$ 0.05). Subsequently, the Pearson ( $r$ ) linear correlation coefficients were calculated for all combinations between the physiological and physical quality tests of the seeds, where the significance of the $r$ values was determined by the $t$ test $(p \leq 0.05)$. Principal component analysis was also performed. The software used in the statistical analysis was $R$, version 3.5.1. 


\section{RESULTS AND DISCUSSION}

The X-ray equipment configurations adopted in this study, combined with the low variation of water content among the evaluated seed lots of each cultivar (cv. Bazuca F1: 8.1 to $8.8 \%$; cv. Goldex F1: 8.0 to 8.9 \%; cv. Pampa F1: 7.8 to 8.7 $\%)$, allowed a clear visualization of the main internal structure of the seeds, as well as the identification of embryonic malformation and physical damages (Figure 1).

The water content of the seeds has a high relation with the optical density of the radiography (Simak, 1991). Therefore, the uniformity of seed water content between seed lots is necessary to compare parameters related to tissue density, as gray levels of the radiographs. Studies carried out with X-ray analysis on pumpkin seeds (Silva et al., 2014), watermelon and melon (Gomes-Junior et al., 2012) demonstrated the possibility of adequate visualization of the internal morphology of seeds under water contents between $6.5 \%$ and $12 \%$.

Besides the water content, the level of detail of the internal seed parts of the radiographic image can be affected by other intrinsic factors of each species, such as its chemical composition (Simak, 1991). In sesame seeds, the X-ray test did not allow the determination of the level of development of internal seed structure, which according to the authors was due to its high oil content, typical of oilseeds (Nogueira-Filho et al., 2017). However, as shown in Figure 1 , in melon seeds, whose oil content is within the range of 25.2 to $44.8 \%$ (Ibeto et al., 2012), it was possible the visualization with a high degree of detail of the internal seed morphology, with easy visual identification of seeds with incomplete filling and embryonic malformation (Figure 1B), as well as physical damage caused by predation of insects and cracks, possibly during handling or drying processes (Figure $1 \mathrm{C}$ ). Thus, it is possible to verify that the X-ray test itself, i.e, the visual analysis of the radiographs, is a suitable tool for studies with oilseeds, such as melon, allowing an accurate analysis of the seed physical quality by simple visual evaluation. Although the evaluation of the $\mathrm{X}$-ray by the analyst is the simplest and most sensitive approach, it is a laborious, time-consuming process as well as subject to errors inherent in its subjectivity.

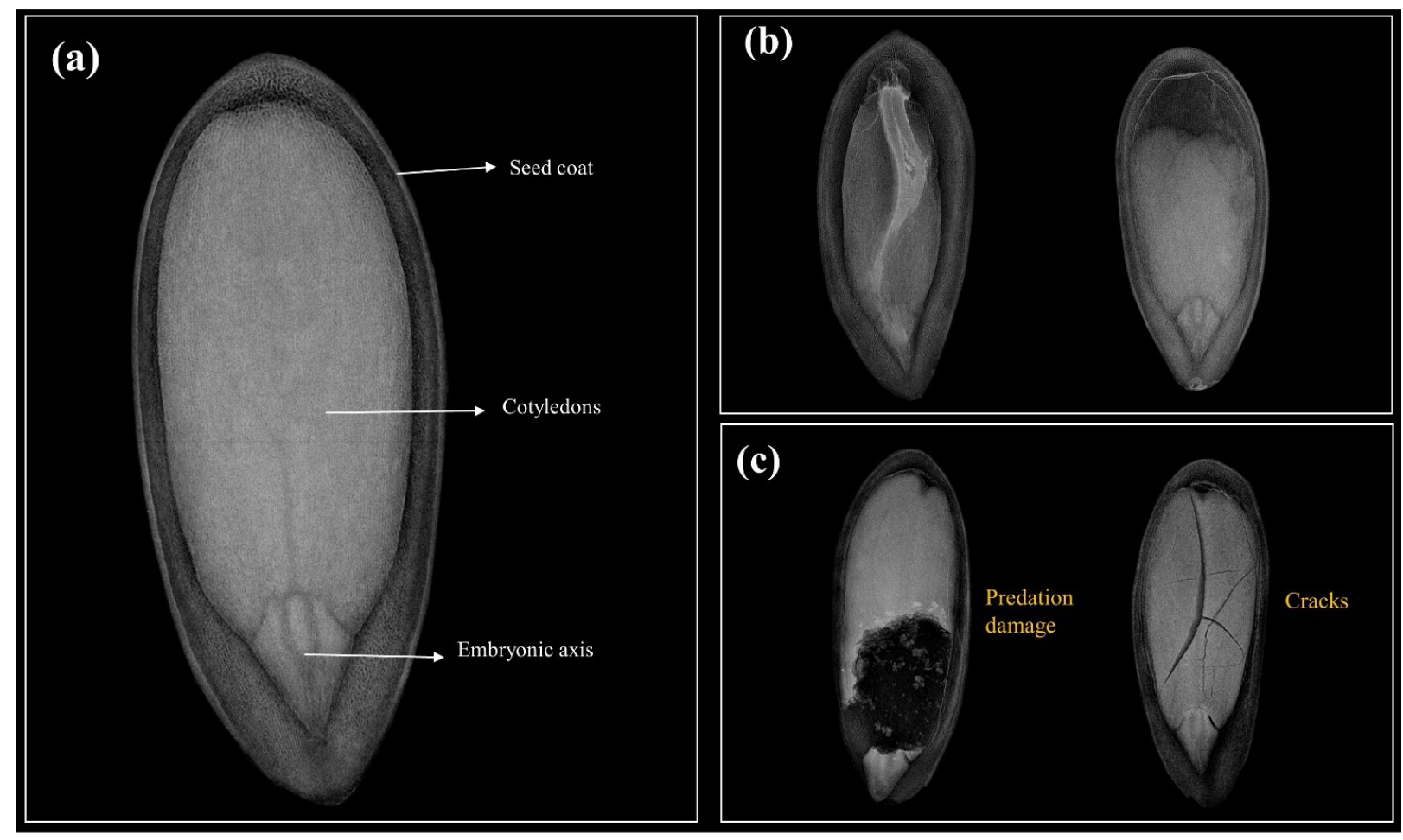

Figure 1. Radiographic images of melon seeds with indications of the internal parts of a well-formed seed (a), seeds with visible embryonic malformation (b) and with physical damages (c). 
Table 1 shows the variables obtained with the use of the PhenoXray macro from ImageJ ${ }^{\circledR}$, which allowed the complete automation of the analysis of seed radiographs of the thirty seed lots of hybrid melon. Statistical differences were observed for most of the analyzed variables, except for relative density and perimeter, between the seed lots of the cultivars Goldex F1 and Pampa F1, respectively.

From the analysis of the size and shape (area, perimeter and circularity), it was evident the different characteristics observed between seed lots of the same cultivar, which was confirmed by the significant difference between the values obtained. For the cultivar Bazuca F1, the values of area, perimeter and circularity ranged from 30.2 to $39.5 \mathrm{~mm}^{2}, 29.7$ to $42.4 \mathrm{~mm}$ and 0.30 to 0.50 , respectively. Seeds of "Goldex F1" showed larger areas in absolute value in relation to the other cultivars, with variation observed from 41.7 to $43.9 \mathrm{~mm}^{2}$; the perimeter and circularity, in turn, ranged from 35.8 to $53.6 \mathrm{~mm}^{2}, 0.23$ to 0.45 , respectively. Finally, the cultivar Pampa F1 showed a variation of 29.2 to $38.0 \mathrm{~mm}^{2}$ of area, 34.4 to $40.6 \mathrm{~mm}$ of perimeter (the lots did not differ in relation to this parameter) and 0.29 to 0.41 of circularity.

According to Tanabata et al. (2012), information on the quantitative evaluation of seeds' shape and size, when obtained by reliable and high throughput methodology, can benefit several fields of plant research, such as plant breeding programs, acting together with functional analysis studies and improvement of genomic assisted crops. Moreover, studies have shown a close relationship between these characteristics and seedling vigor (Abud et al., 2018; Javorski et al., 2018; Medeiros et al., 2018), since the variability of seed size and shape may be related to the environment during the maturation process.

The variables relative density, integrated density and filling allowed to stratify from two to four groups the ten seed lots of each cultivar. The relative and integrated densities are variables only recently reported in seed research, and with great potential for seed lots' evaluation (Abud et al., 2018; Medeiros et al. 2018). On the other hand, the filling variable has already been evaluated in a larger number of studies (Gomes-Junior et al., 2013), but not fully automated using ImageJ ${ }^{\bullet}$ software. These variables, calculated by means of the gray values of each pixel in the image, give an idea of the resistance that a given tissue presents to the passage of X-rays, since the photons in an $\mathrm{X}$-ray beam can be transmitted, scattered (Compton dispersion) or absorbed (photoelectric collision) when they collide with an object (Kotwaliwale et al., 2014). Thus, higher gray densities indicate denser tissues, that is, there is greater impediment to X-ray passages.

Several authors pointed out that the evaluation of aspects such as the internal cavity occupied by the embryo, the presence of mechanical damages, stains that indicate tissue deterioration or seed malformations is necessary in studies with X-rays in seeds (Borges et al., 2019; Gomes-Junior et al., 2013). However, according to Medeiros et al. (2018), all these characteristics are in a way represented by the relative density, since seeds deteriorated or with less filling show lower gray levels in the radiographic image. Thus, the image presents lower levels of radiopacity (light) and higher levels of radioluminescence (dark), which can be quantified by means of relative density.

It is important to emphasize that for a comparison between seed relative densities from different radiographs, the contrast used by the equipment in calibrating the image (width and center adjustment) must be standardized in all of them. In addition, the relative density is influenced by other objects with higher density that are inserted with the seeds in the acquisition of the image, such as fruit remnants, stones and other types of impurities. Another important point is that different X-ray systems, even using analogous configurations of energy and electrical current may not produce similar results, because of the types of X-ray detectors used (Kotwaliwale et al., 2014).

With the filling variable, which represents the percentage of area of the seed effectively filled by high density material, we noticed that the lowest observed averages value was $93.6 \%$, which indicates high uniformity of embryonic filling perceived in the seed lots studied. Borges et al. (2019) also used the filling variable to quantify the empty seed area of tomato, and observed a close relationship between seed empty space and its physiological quality.

Although the physical parameters generated from X-ray image analysis are initially interesting and efficient in differentiating seed lots, it is necessary to check the physiological quality data from the seeds of the respective lots to make a precise inference about a possible relation of these variables with the seed physiological potential. 
Table 1. Average values of the physical parameters obtained through the automated analysis of radiographic images of 30 lots of hybrid melon seeds using the PhenoXray macro.

\begin{tabular}{|c|c|c|c|c|c|c|}
\hline \multirow[t]{2}{*}{ Seed lot } & $\begin{array}{l}\text { Area } \\
\mathrm{mm}^{2}\end{array}$ & $\begin{array}{l}\text { Per. } \\
\mathrm{mm}\end{array}$ & Circ. & $\begin{array}{l}\text { Rel. dens. } \\
\text { gray.pixel }{ }^{-1}\end{array}$ & $\begin{array}{l}\text { Int. dens. } \\
\text { gray.mm². } \text { pixel }^{-1}\end{array}$ & $\begin{array}{c}\text { Filling } \\
\%\end{array}$ \\
\hline & \multicolumn{6}{|c|}{ Cultivar Bazuca F1 } \\
\hline 1 & $34.56 \mathrm{~b}$ & $29.69 d$ & $0.496 a$ & $94.29 \mathrm{a}$ & $3261 b$ & 99 a \\
\hline 2 & $35.29 \mathrm{~b}$ & $31.28 \mathrm{c}$ & $0.460 \mathrm{~b}$ & $92.15 \mathrm{a}$ & $3254 \mathrm{~b}$ & $98 \mathrm{a}$ \\
\hline 3 & $30.18 \mathrm{c}$ & $31.92 \mathrm{c}$ & $0.401 \mathrm{c}$ & $88.63 \mathrm{~b}$ & $2678 c$ & 98 a \\
\hline 4 & $30.79 c$ & $39.14 \mathrm{~b}$ & $0.295 \mathrm{~d}$ & $85.73 b$ & $2637 c$ & $96 b$ \\
\hline 5 & $39.50 \mathrm{a}$ & $32.50 \mathrm{c}$ & $0.474 \mathrm{~b}$ & $97.04 \mathrm{a}$ & 3833 a & $98 \mathrm{a}$ \\
\hline 6 & $38.12 \mathrm{a}$ & $41.35 \mathrm{a}$ & $0.309 \mathrm{~d}$ & $87.27 \mathrm{~b}$ & $3328 \mathrm{~b}$ & $95 \mathrm{c}$ \\
\hline 7 & $38.05 \mathrm{a}$ & $42.38 \mathrm{a}$ & $0.302 \mathrm{~d}$ & $85.72 \mathrm{~b}$ & $3263 b$ & $95 \mathrm{c}$ \\
\hline 8 & $37.34 \mathrm{a}$ & $40.07 \mathrm{~b}$ & $0.317 \mathrm{~d}$ & $89.58 b$ & $3344 \mathrm{~b}$ & $95 \mathrm{c}$ \\
\hline 9 & $38.35 \mathrm{a}$ & $41.05 \mathrm{a}$ & $0.314 \mathrm{~d}$ & $88.61 \mathrm{~b}$ & $3399 \mathrm{~b}$ & $95 \mathrm{c}$ \\
\hline 10 & $30.97 c$ & $33.11 \mathrm{c}$ & $0.389 \mathrm{c}$ & $80.00 \mathrm{c}$ & $2479 c$ & $94 \mathrm{~d}$ \\
\hline $\mathrm{Fc}$ & $46.60^{*}$ & $52.08^{*}$ & $65.51^{*}$ & $10.01^{*}$ & $28.60^{*}$ & $78.53^{*}$ \\
\hline \multirow[t]{2}{*}{ CV (\%) } & 3.28 & 4.23 & 5.78 & 3.83 & 5.55 & 0.49 \\
\hline & \multicolumn{6}{|c|}{ Cultivar Goldex F1 } \\
\hline 12 & $43.11 \mathrm{a}$ & $37.04 \mathrm{c}$ & $0.408 a$ & 95.1 & 4102 a & 98 a \\
\hline 12 & $41.67 \mathrm{~b}$ & $38.18 \mathrm{c}$ & $0.395 \mathrm{a}$ & 88.76 & $3706 \mathrm{~b}$ & $97 a$ \\
\hline 13 & $43.50 \mathrm{a}$ & $36.67 c$ & $0.420 \mathrm{a}$ & 91.19 & 3970 a & $97 a$ \\
\hline 14 & $43.37 \mathrm{a}$ & $35.84 \mathrm{c}$ & $0.441 \mathrm{a}$ & 93.69 & 4062 a & $98 a$ \\
\hline 15 & $43.80 \mathrm{a}$ & $36.07 c$ & $0.445 \mathrm{a}$ & 89.28 & 3914 a & 98 a \\
\hline 16 & $42.50 \mathrm{~b}$ & $49.80 \mathrm{~b}$ & $0.254 \mathrm{~b}$ & 88.31 & $3762 b$ & $94 \mathrm{c}$ \\
\hline 17 & $41.93 \mathrm{~b}$ & $50.32 \mathrm{~b}$ & $0.243 b$ & 86.32 & $3622 b$ & $93 \mathrm{c}$ \\
\hline 18 & $42.46 \mathrm{~b}$ & $49.88 \mathrm{~b}$ & $0.266 \mathrm{~b}$ & 87.01 & $3707 b$ & $93 \mathrm{c}$ \\
\hline 19 & $43.89 a$ & $46.89 \mathrm{~b}$ & $0.287 \mathrm{~b}$ & 92.89 & 4081 a & $96 \mathrm{~b}$ \\
\hline 20 & $42.51 \mathrm{~b}$ & $53.60 \mathrm{a}$ & $0.234 \mathrm{~b}$ & 84.54 & $3603 \mathrm{~b}$ & $93 \mathrm{c}$ \\
\hline Fc & $4.11^{*}$ & $30.40^{*}$ & $25.24^{*}$ & $1.50^{\text {ns }}$ & $2.27^{*}$ & $84.26^{*}$ \\
\hline \multirow[t]{2}{*}{ CV (\%) } & 1.99 & 6.76 & 11.71 & 6.95 & 7.5 & 0.52 \\
\hline & \multicolumn{6}{|c|}{ Cultivar Pampa F1 } \\
\hline 21 & $29.19 \mathrm{~d}$ & 37.17 & $0.349 \mathrm{~b}$ & $90.78 \mathrm{~b}$ & $2665 \mathrm{~b}$ & $95 \mathrm{a}$ \\
\hline 22 & $34.26 \mathrm{~b}$ & 37.38 & $0.333 \mathrm{~b}$ & $91.43 \mathrm{~b}$ & $3136 a$ & $94 \mathrm{~b}$ \\
\hline 23 & $32.52 \mathrm{c}$ & 34.67 & $0.356 \mathrm{~b}$ & $97.97 \mathrm{a}$ & 3195 a & 95 a \\
\hline 24 & $34.25 b$ & 34.4 & $0.376 \mathrm{a}$ & $102.15 \mathrm{a}$ & 3502 a & $96 a$ \\
\hline 25 & $35.17 b$ & 35.03 & $0.382 \mathrm{a}$ & 99.89 a & 3531 a & $96 a$ \\
\hline 26 & $37.31 \mathrm{a}$ & 35.5 & $0.399 a$ & $88.69 \mathrm{~b}$ & 3313 a & $96 a$ \\
\hline 27 & $36.67 \mathrm{a}$ & 34.59 & $0.409 a$ & $89.66 \mathrm{~b}$ & 3291 a & $96 a$ \\
\hline 28 & $37.27 \mathrm{a}$ & 35.13 & $0.403 \mathrm{a}$ & $89.01 \mathrm{~b}$ & 3324 a & $96 a$ \\
\hline 29 & $38.00 \mathrm{a}$ & 35.9 & 0.399 a & $89.40 \mathrm{~b}$ & 3402 a & $96 a$ \\
\hline 30 & $32.10 \mathrm{c}$ & 40.6 & $0.288 \mathrm{~b}$ & $78.80 \mathrm{c}$ & $2532 b$ & $95 b$ \\
\hline $\mathrm{Fc}$ & $42.50^{*}$ & $1.04^{\mathrm{ns}}$ & $3.69^{*}$ & $4.54^{*}$ & $9.54^{*}$ & $5.39^{*}$ \\
\hline CV (\%) & 2.77 & 11.58 & 12.06 & 7.7 & 7.62 & 0.82 \\
\hline
\end{tabular}

Lower case $=$ comparison within each column for each evaluation by the Scott-Knott test $(p<0.05) ;{ }^{*}$, ns = significant and not significant by the $\mathrm{F}$ test $(\mathrm{p}<0.05)$, respectively; Fc = F calculated; $\mathrm{CV}=$ coefficient of variation; Per. = perimeter; Circ. = circularity; Rel. dens. = relative density; Int. dens. = integrated density. 
Table 2 presents the variables obtained through the evaluation of the physiological potential of melon seeds. Statistical differences were detected for most of the variables, except for the germination synchrony variable, among the lots of the cultivar Pampa F1.

Percentage of germination representing the percentage of normal seedlings at eight days after sowing, showed that all seed lots, except lot 10 , produced values greater than $80 \%$ of germination, which is the minimum value established for the marketing of melon seeds in Brazil, indicating high viability of the seeds. For the primary root protrusion, the same pattern was observed for the germination data; however, the values were generally higher because of the evaluation considering only the emission of the primary root $(>2 \mathrm{~mm})$, not necessarily culminating in the formation of a normal seedling.

From the data of the speed of germination index (GSI), speed of primary root protrusion (RPS) and synchrony, it can be observed grouping in up to four levels for cultivar Bazuca F1, five levels for Goldex F1 and four levels for Pampa F1. These results indicate significant differences in germination timing and in the rates of germination and primary root protrusion between the seed lots. According to Finch-Savage and Bassel (2016), this is an important information, since the irregular seedling emergence of seedlings can lead to phenological delays and variations in plant growth in further phenological stages, also affecting harvesting.

Seedling image analysis using Image $^{\circ}$ software allowed the identification of differences in seedling growth and uniformity of the different seed lots, expressed by means of seedling length and uniformity, vigor and corrected vigor indexes (Table 2). For the cultivars Bazuca F1 and Pampa F1, the variable length of seedling was more sensitive than the germination test to detect differences between the lots. It was also observed that for some seed lots that presented a high percentage of germination (for example, lots 1, 2, 3,5), smaller values of average seedling length were observed, which shows a high viability of the seeds, however this lower growth can be an indication of low vigor.

By means of the seedling uniformity index (Table 2), some lots with lower performance in the average seedling length showed high uniformity in their development, or vice versa, that is, Lot 1 and Lot 6, respectively. Other authors have pointed out that the uniformity of seedling development is an index that should be taken into account in the evaluation of seed lots, since it can provide useful information on the degree of deterioration, initial growth potential and seedling emergence uniformity (Leão-Araújo et al., 2019).

For the vigor index, which considers the growth rate and seedling uniformity, the previous results were confirmed, highlighting differences of physiological potential in at least two levels to cultivar Goldex F1 and in three levels for the other cultivars. The corrected vigor index, which consists of the vigor index product with the germination percentage, was efficient to detect differences in at least four vigor levels among the seed lots of the three cultivars. For Medeiros and Pereira (2018), the corrected vigor index makes a more efficient beaconing of the results of the vigor index, since it performs an adjustment based on germination, offering a more representative result of the physiological potential of the seeds.

In general, the data obtained for the different seed lots and cultivars indicate differences in seed physiological quality (Table 2). Significant differences were also observed between the lots of the three cultivars when considering the physical parameters obtained from the X-ray images, such as relative density, integrated density and filling (Table 1). However, to verify possible relationships between the physical variables, obtained by the automated analysis of radiographs, with the variables of physiological potencial, obtained through the test of germination and seedling growth, a correlation analysis was performed (Figure 2).

Significant correlations $(p<0.05)$ of some descriptors of size and shape with physiological quality were observed. For the cultivar Bazuca F1, the seed area showed correlation with seedling length $(r=0.71)$, vigor index $(r=0.77)$ and corrected vigor $(r=0.67)$. The perimeter and the circularity were correlated only with the germination synchrony $(r=-0.65$ and $r=0.67$, respectively). For the cultivar Goldex F1, only the perimeter and the circularity presented correlations with the variables of physiological quality (for example, germination: $r=-0.92$ and $r=0.87$; GSI: $r=-0.82$ and $r=0.75$; RPS: $r=$ -0.91 and $r=0.88$; uniformity: $r=-0.86$ and $r=0.80$; vigor: $r=-0.81$ and $r=0.76$; corrected vigor: $r=-0.89$ and $r=0.85$, 
Table 2. Average values of the data obtained in the evaluation of the physiological potential of thirty lots of hybrid melon seeds.

\begin{tabular}{|c|c|c|c|c|c|c|c|c|c|}
\hline \multirow{3}{*}{ Seed lot } & Germ. & Rad. pro. & \multirow{2}{*}{ GSI } & \multirow{2}{*}{ RPS } & \multirow{2}{*}{ Sync } & SL & Unif. & Vigor & Corr. vigor \\
\hline & \multicolumn{2}{|c|}{$\%$} & & & & $\mathrm{~mm}$ & & Index & \\
\hline & \multicolumn{9}{|c|}{ Cultivar Bazuca F1 } \\
\hline 1 & $95 \mathrm{a}$ & $100 \mathrm{a}$ & $6.33 \mathrm{a}$ & $11.8 \mathrm{~b}$ & $1.00 \mathrm{a}$ & $9.24 \mathrm{c}$ & $892 \mathrm{a}$ & $770 \mathrm{~b}$ & $731 b$ \\
\hline 2 & $94 \mathrm{a}$ & $100 \mathrm{a}$ & $6.27 \mathrm{a}$ & $14.2 \mathrm{a}$ & $1.00 \mathrm{a}$ & $9.50 \mathrm{c}$ & $871 \mathrm{a}$ & $768 b$ & $722 b$ \\
\hline 3 & $95 \mathrm{a}$ & $97 a$ & $6.18 \mathrm{a}$ & $12.0 \mathrm{~b}$ & $0.90 \mathrm{~b}$ & $9.41 \mathrm{c}$ & $868 \mathrm{a}$ & $763 b$ & $725 b$ \\
\hline 4 & $86 b$ & $90 \mathrm{~b}$ & $5.54 \mathrm{~b}$ & $10.9 \mathrm{~b}$ & $0.84 \mathrm{~b}$ & $8.08 \mathrm{~d}$ & $790 \mathrm{~b}$ & $678 c$ & $583 \mathrm{c}$ \\
\hline 5 & $97 a$ & $98 a$ & $6.30 \mathrm{a}$ & $11.4 \mathrm{~b}$ & $0.88 \mathrm{~b}$ & $9.47 \mathrm{c}$ & $882 \mathrm{a}$ & 772 b & $749 \mathrm{~b}$ \\
\hline 6 & $94 a$ & 99 a & $5.97 a$ & $11.2 \mathrm{~b}$ & $0.69 \mathrm{c}$ & $12.56 \mathrm{a}$ & $835 b$ & $857 a$ & $806 \mathrm{a}$ \\
\hline 7 & $85 b$ & $100 \mathrm{a}$ & $5.23 \mathrm{~b}$ & $10.6 \mathrm{~b}$ & $0.60 \mathrm{c}$ & $11.45 b$ & $817 b$ & $809 \mathrm{~b}$ & $688 \mathrm{~b}$ \\
\hline 8 & $95 \mathrm{a}$ & 99 a & $5.90 \mathrm{a}$ & $10.0 \mathrm{~b}$ & $0.61 c$ & $12.35 \mathrm{~b}$ & $856 a$ & $860 a$ & $817 a$ \\
\hline 9 & $93 a$ & $99 \mathrm{a}$ & $5.57 \mathrm{a}$ & $11.0 \mathrm{~b}$ & $0.54 \mathrm{~d}$ & $11.86 \mathrm{a}$ & $866 a$ & $848 \mathrm{a}$ & 789 a \\
\hline 10 & $64 c$ & $76 \mathrm{c}$ & $3.75 \mathrm{c}$ & $7.4 \mathrm{c}$ & $0.47 \mathrm{~d}$ & $8.96 \mathrm{c}$ & $660 c$ & $644 \mathrm{c}$ & $412 \mathrm{~d}$ \\
\hline $\mathrm{Fc}$ & $9.15^{*}$ & $23.38^{*}$ & $16.44^{*}$ & $13.73^{*}$ & $17.67^{*}$ & $28.30^{*}$ & $12.46^{*}$ & $14.05^{*}$ & $52.51^{*}$ \\
\hline \multirow[t]{2}{*}{ CV (\%) } & 8.15 & 3.65 & 7.55 & 9.3 & 13.8 & 6.53 & 5.2 & 5.58 & 5.36 \\
\hline & \multicolumn{9}{|c|}{ Cultivar Goldex F1 } \\
\hline 11 & $98 \mathrm{a}$ & $100 \mathrm{a}$ & $6.45 \mathrm{a}$ & $19.3 \mathrm{a}$ & $0.91 \mathrm{a}$ & $13.36 \mathrm{a}$ & $864 a$ & 899 a & $881 \mathrm{a}$ \\
\hline 12 & $98 a$ & $99 \mathrm{a}$ & $6.14 \mathrm{a}$ & $18.5 \mathrm{a}$ & $0.67 \mathrm{~b}$ & $10.83 \mathrm{~b}$ & $864 a$ & $811 b$ & $795 \mathrm{~b}$ \\
\hline 13 & $96 a$ & $100 \mathrm{a}$ & $6.19 a$ & $17.4 \mathrm{~b}$ & $0.82 \mathrm{a}$ & $12.41 \mathrm{a}$ & $857 a$ & $863 a$ & $828 \mathrm{~b}$ \\
\hline 14 & 99 a & $100 \mathrm{a}$ & $6.26 \mathrm{a}$ & $18.2 \mathrm{a}$ & $0.69 \mathrm{~b}$ & $12.66 \mathrm{a}$ & $874 a$ & $880 \mathrm{a}$ & $871 \mathrm{a}$ \\
\hline 15 & $93 \mathrm{a}$ & 98 a & $5.77 b$ & $17.4 \mathrm{~b}$ & $0.60 \mathrm{~b}$ & $12.00 \mathrm{~b}$ & $816 b$ & $828 b$ & $770 \mathrm{~b}$ \\
\hline 16 & $89 \mathrm{~b}$ & 99 a & $5.62 b$ & $14.1 \mathrm{c}$ & $0.65 b$ & $11.36 \mathrm{~b}$ & $795 b$ & $795 b$ & $708 \mathrm{c}$ \\
\hline 17 & $89 b$ & $98 \mathrm{a}$ & $5.75 b$ & $12.4 \mathrm{~d}$ & $0.79 \mathrm{a}$ & $11.79 b$ & $813 b$ & $819 b$ & $729 c$ \\
\hline 18 & $85 \mathrm{~b}$ & $100 \mathrm{a}$ & $5.47 \mathrm{~b}$ & $14.6 \mathrm{c}$ & $0.75 \mathrm{~b}$ & $11.23 \mathrm{~b}$ & $748 \mathrm{c}$ & $767 \mathrm{~b}$ & $652 \mathrm{~d}$ \\
\hline 19 & $91 \mathrm{~b}$ & $97 a$ & $6.02 \mathrm{a}$ & $12.0 \mathrm{~d}$ & $0.94 \mathrm{a}$ & $11.93 \mathrm{~b}$ & $806 \mathrm{~b}$ & $820 \mathrm{~b}$ & $747 c$ \\
\hline 20 & $84 \mathrm{~b}$ & $93 \mathrm{~b}$ & $5.30 \mathrm{~b}$ & $9.1 \mathrm{e}$ & $0.65 \mathrm{~b}$ & $10.84 \mathrm{~b}$ & $747 c$ & $753 \mathrm{~b}$ & $633 d$ \\
\hline Fc & $4.18^{*}$ & $3.89^{*}$ & $4.48^{*}$ & $57.22^{*}$ & $4.88^{*}$ & $3.45^{*}$ & $4.66^{*}$ & $3.87^{*}$ & $15.54^{*}$ \\
\hline \multirow[t]{2}{*}{ CV (\%) } & 7.11 & 2.26 & 7.31 & 6.51 & 15.49 & 8.28 & 5.86 & 6.44 & 6.32 \\
\hline & \multicolumn{9}{|c|}{ Cultivar Pampa F1 } \\
\hline 21 & $96 a$ & $100 \mathrm{a}$ & $6.24 \mathrm{a}$ & $19.4 \mathrm{a}$ & 0.88 & $11.77 \mathrm{c}$ & $849 \mathrm{~b}$ & $836 \mathrm{~b}$ & $803 b$ \\
\hline 22 & $94 \mathrm{a}$ & $97 b$ & $5.98 \mathrm{~b}$ & $18.4 \mathrm{~b}$ & 0.78 & $11.50 \mathrm{~d}$ & $809 \mathrm{~b}$ & $807 c$ & $759 c$ \\
\hline 23 & $97 a$ & $100 \mathrm{a}$ & $6.29 a$ & $19.7 \mathrm{a}$ & 0.86 & $12.96 \mathrm{~b}$ & $816 b$ & $861 \mathrm{~b}$ & $836 \mathrm{~b}$ \\
\hline 24 & $100 \mathrm{a}$ & $100 \mathrm{a}$ & $6.61 \mathrm{a}$ & $20.0 \mathrm{a}$ & 0.94 & $14.54 \mathrm{a}$ & $917 \mathrm{a}$ & $967 a$ & $967 a$ \\
\hline 25 & $98 a$ & $100 \mathrm{a}$ & $6.44 \mathrm{a}$ & $18.0 \mathrm{~b}$ & 0.92 & $13.93 \mathrm{a}$ & $898 \mathrm{a}$ & $936 \mathrm{a}$ & $918 \mathrm{a}$ \\
\hline 26 & $91 \mathrm{~b}$ & 99 a & $5.88 \mathrm{~b}$ & $19.0 \mathrm{a}$ & 0.78 & $12.11 \mathrm{c}$ & $778 \mathrm{c}$ & $813 c$ & $740 \mathrm{c}$ \\
\hline 27 & $87 \mathrm{~b}$ & $99 a$ & $5.55 \mathrm{~b}$ & $19.2 \mathrm{a}$ & 0.71 & $11.41 \mathrm{~d}$ & $758 \mathrm{c}$ & $778 \mathrm{c}$ & $677 d$ \\
\hline 28 & $97 a$ & $100 \mathrm{a}$ & $6.28 \mathrm{a}$ & $18.8 \mathrm{a}$ & 0.79 & $12.43 c$ & $825 b$ & $848 b$ & $822 b$ \\
\hline 29 & $97 \mathrm{a}$ & $100 \mathrm{a}$ & $6.35 a$ & $17.6 \mathrm{~b}$ & 0.87 & $12.25 \mathrm{c}$ & $840 \mathrm{~b}$ & $849 \mathrm{~b}$ & $823 \mathrm{~b}$ \\
\hline 30 & $92.5 \mathrm{~b}$ & $100 \mathrm{a}$ & $6.00 \mathrm{~b}$ & $10.7 \mathrm{c}$ & 0.81 & $10.70 \mathrm{~d}$ & $815 b$ & $782 \mathrm{c}$ & $719 c$ \\
\hline $\mathrm{Fc}$ & $4.05^{*}$ & $2.69^{*}$ & $4.93^{*}$ & $62.49^{*}$ & $1.83^{\text {ns }}$ & $11.93^{*}$ & $6.40^{*}$ & $9.32^{*}$ & $21.18^{*}$ \\
\hline CV (\%) & 4.51 & 1.33 & 5.05 & 4.22 & 14.07 & 6.14 & 5.2 & 5.35 & 5.34 \\
\hline
\end{tabular}

Lowercase = comparison within each column for each evaluation by the Scott-Knott test $(p<0.05) ;{ }^{*}$, ns = significant and not significant by the $F$ test $(p<0.05) ; F c=$ F calculated; CV = coefficient of variation; Germ. = germination; Rad. pro. = radicle protrusion; GSI = germination speed index; RPS = root protrusion speed; sync = synchrony; $\mathrm{SL}$ = seedlings length; Unif = Uniformity; Corr. vigor = corrected vigor. 
respectively). Finally, for the cultivar Pampa F1, there was a significant correlation only of the RPS with the perimeter and the circularity ( $r=-0.86$ and $r=0.68$, respectively).

There are also strong and significant correlations between the variables related to tissue density and filling of the seeds with the variables of physiological quality (Figure 2). In general, the responses of the cultivars did not follow the same trend, which can be explained by the history of the lots and the different characteristics of the seed of each cultivar. For the cultivar Pampa F1, for example, the lots showed narrow variation in the percentage of germination and a wide variation in vigor, observed by more evident differences in the length of seedlings, which may have led to a lower correlation of X-ray variables with germination $(r<0.60)$ and higher correlations with variables related to seedling length (for example, relative density: $r=0.90$ ).

The high correlations observed for the parameters: relative density, integrated density and filling with the physiological variables are important indicators for the validation of the methodology of automated analysis of X-ray images to evaluate seed quality. Abud et al. (2018) and Medeiros et al. (2018) also observed high correlations between the relative density variable, obtained from radiographs of broccoli and leucena seeds, respectively, with variables of physiological quality, especially the seedling length. This indicate that the relative density parameter is promising to estimate the physiological potential of these seeds.

In Figure 3 it is possible to identify the association between physical characteristics and the physiological quality of seeds. It was observed that tissues with high integrity generated more opaque images, with zones of high density (shown in green, yellow and red), as the resistance to the passage of X-rays was greater. When these high-density zones were uniform throughout the seed, the relative density remained high and culminated in the emergence of more vigorous

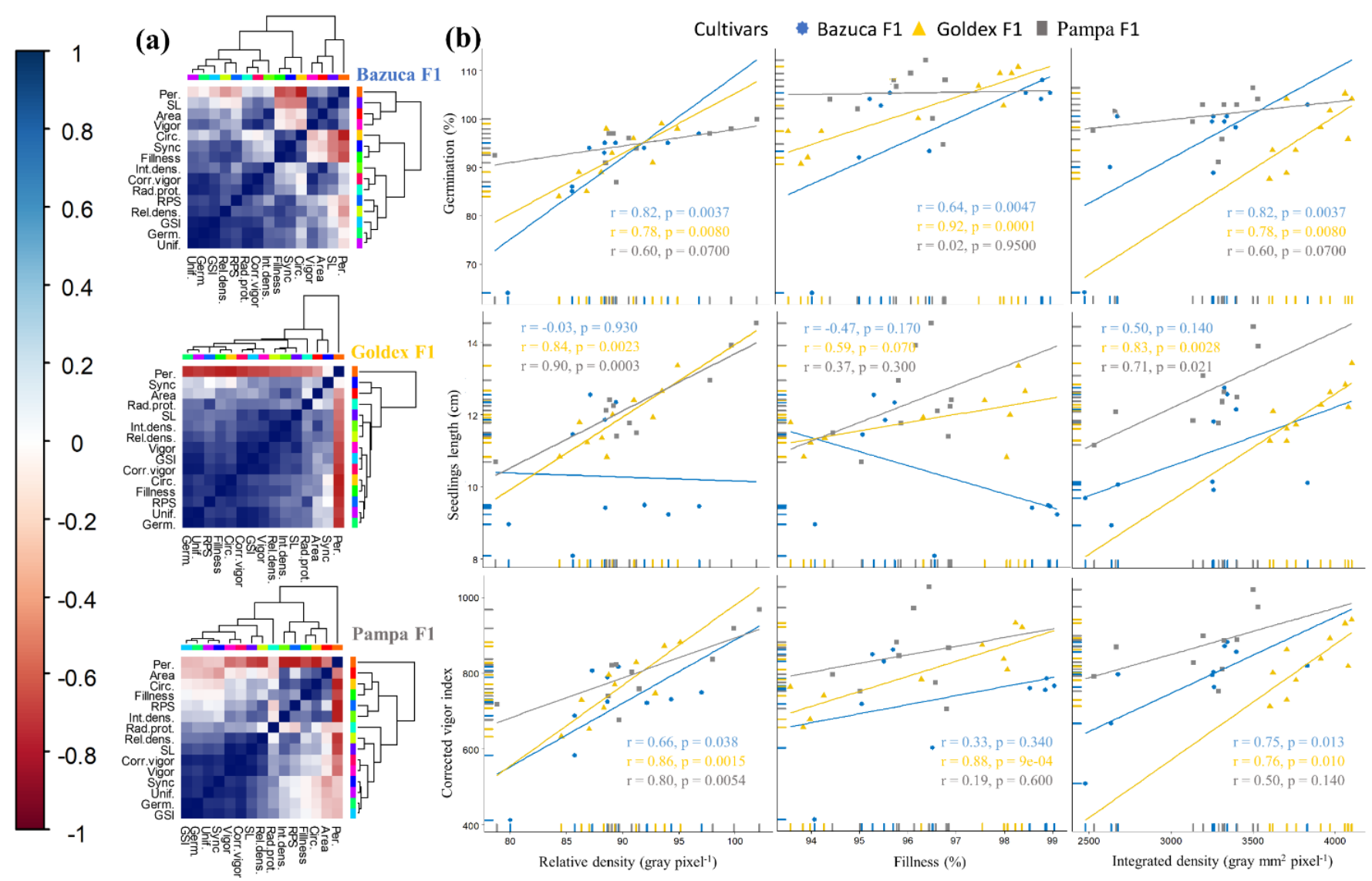

Figure 2. Pearson correlation represented by heatmap (a) and by curves (b) between the generated variables of the automated analysis of the radiographs and the evaluation of germination and seedling length for each hybrid melon cultivar. 
seedlings (Figure 3A). On the other hand, seeds with low integrity tissues possessed lower relative densities, due to the low resistance to X-rays, which generated more translucent or darkened zones in the radiography (represented in the colors blue and purple), and that may be related to the seedlings less developed (Figure 3B). In other cases, it is possible to detect physical damages, such as cracks or predation by insects, represented by bands or centers of low density that lead to the fall in the values of relative density. However, since this damage does not compromise the embryonic axis, germination can occur and lead to the development of normal seedlings (Figures 3C and 3D).

According to some authors, such as Silva et al. (2014), this relationship observed in Figure 3 is not always true, since seeds classified as well formed by the X-ray technique can give rise to abnormal seedlings or dead seeds, and since the radiography allows to verify if there are or not tissue malformation, but does not necessarily establish a direct relationship with physiological processes. However, in this work, it was possible to suppose that even if the physical and physiological variables are not $100 \%$ correlated; there might be a strong association between them, which can lead to advances in procedures of pre-selection of seed lots by farmers and by the seed industry.

It is important to note that the time spent in the analysis of a radiograph from twenty-seed samples each using the PhenoXray macro was only 0.5 seconds (using an Intel Core i5-4200U CPU $1.60 \mathrm{GHz}$ processor). Thus, it is a fast, reproducible, standardized, easy and inexpensive method to measure the physical characteristics of the seeds, which, according to Huang et al. (2015), contributes to guarantee quality seeds for sowing.

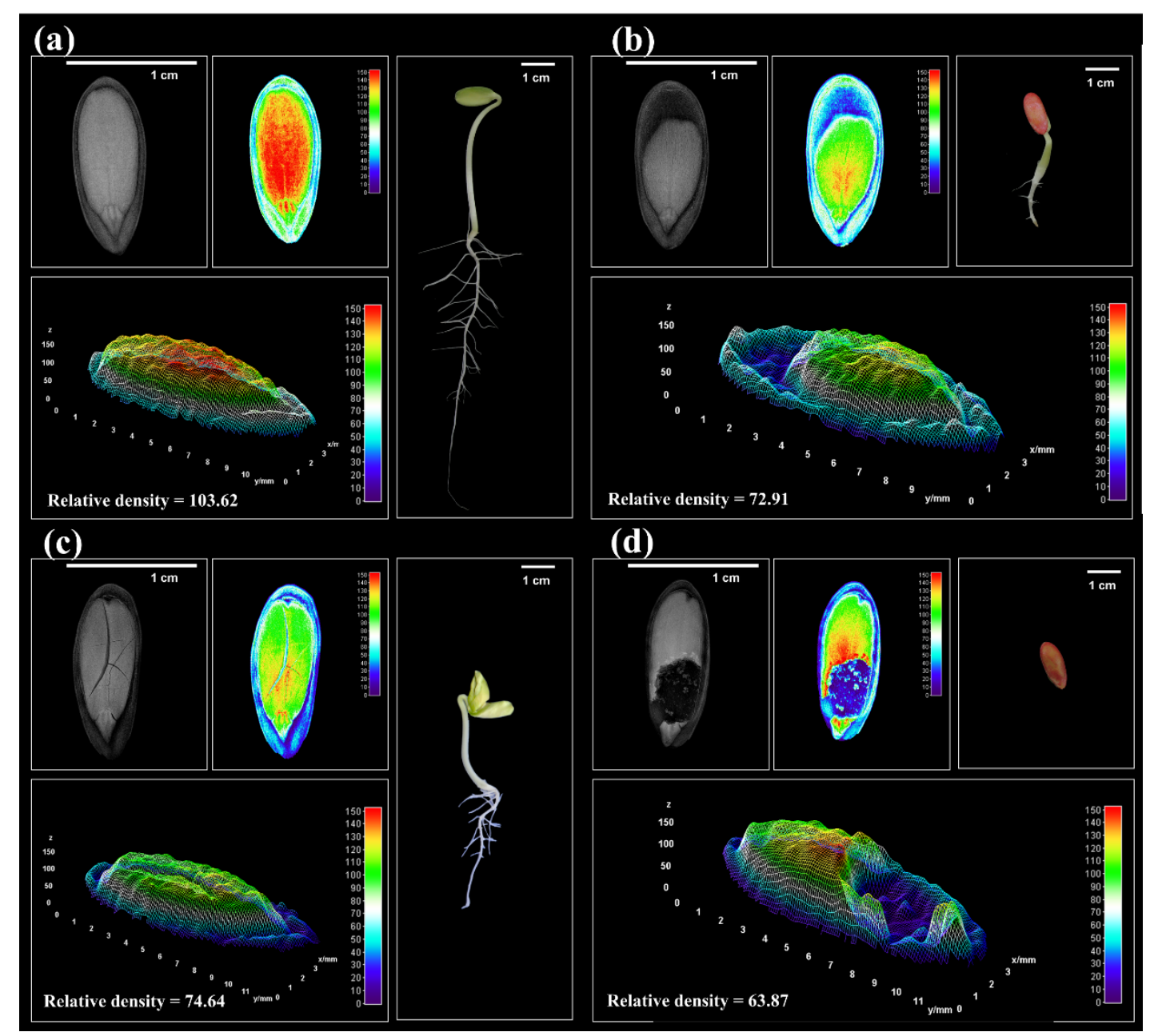

Figure 3. Radiographic images of melon seeds, combined with color representations (2D and 3D) of the density along the seed and its respective seedlings. 
From the multivariate principal component analysis (PCA), using the set of data obtained for the three cultivars and the fifteen characteristics evaluated, it can be noticed that the first two components (PC1 and PC2) accounted for $71.2 \%$ of the variability of the data. Thus, by means of several linear combinations, it was possible to reduce from fifteen dimensions to only two, which explained a significant percentage of the observations (Figure 4).

It was observed that there was a greater dispersion of the seed lots of the cultivar Bazuca F1 by the central ordering diagram, indicating the high variability among the lots for the characteristics that constituted the PCA. In contrast, a larger grouping of the lots of the cultivar Pampa F1 was observed, confirming previous results related to the uniformity of the lots of this hybrid, as observed for the data obtained in the physical and physiological analyses (Tables 1 and 2). In general, the seed lots that were distant and opposite to the vectors of physical and physiological quality (represented in the circle of correlations centered on the right side of the central ordering diagram) were the ones that presented the lowest values for these characteristics.

In the circle of correlations (Figure 4), the vectors that comprise the variables obtained from the automated analysis of the radiographs were close to the vectors of physiological quality, presenting, in turn, factorial loads with similar distribution in the components. These results indicate a high correlation between the characteristics, as already demonstrated in the correlation matrix (Figure 3). Thus, these variables were efficient to determine the level of physical integrity of the seeds, besides being associated to the physiological quality, such as viability and vigor.

Therefore, the use of the PhenoXray macro, developed in Image ${ }^{\circ}$ for the automated analysis of seed radiographs, allows the large-scale analysis, in a fast and consistent way, with promising parameters related to the physical integrity of the seed and related to its physiological potential. The use of Image $J^{\circ}$ for algorithm development and subsequent creation of customizable macros has been successfully reported in other studies (Legland et al., 2017; Miart et al., 2018; Tello et al., 2018; Vasseur et al., 2018) and represents a significant advance for both the automation of analysis and the free diffusion of technologies at the global level, by the opensource nature of the software.
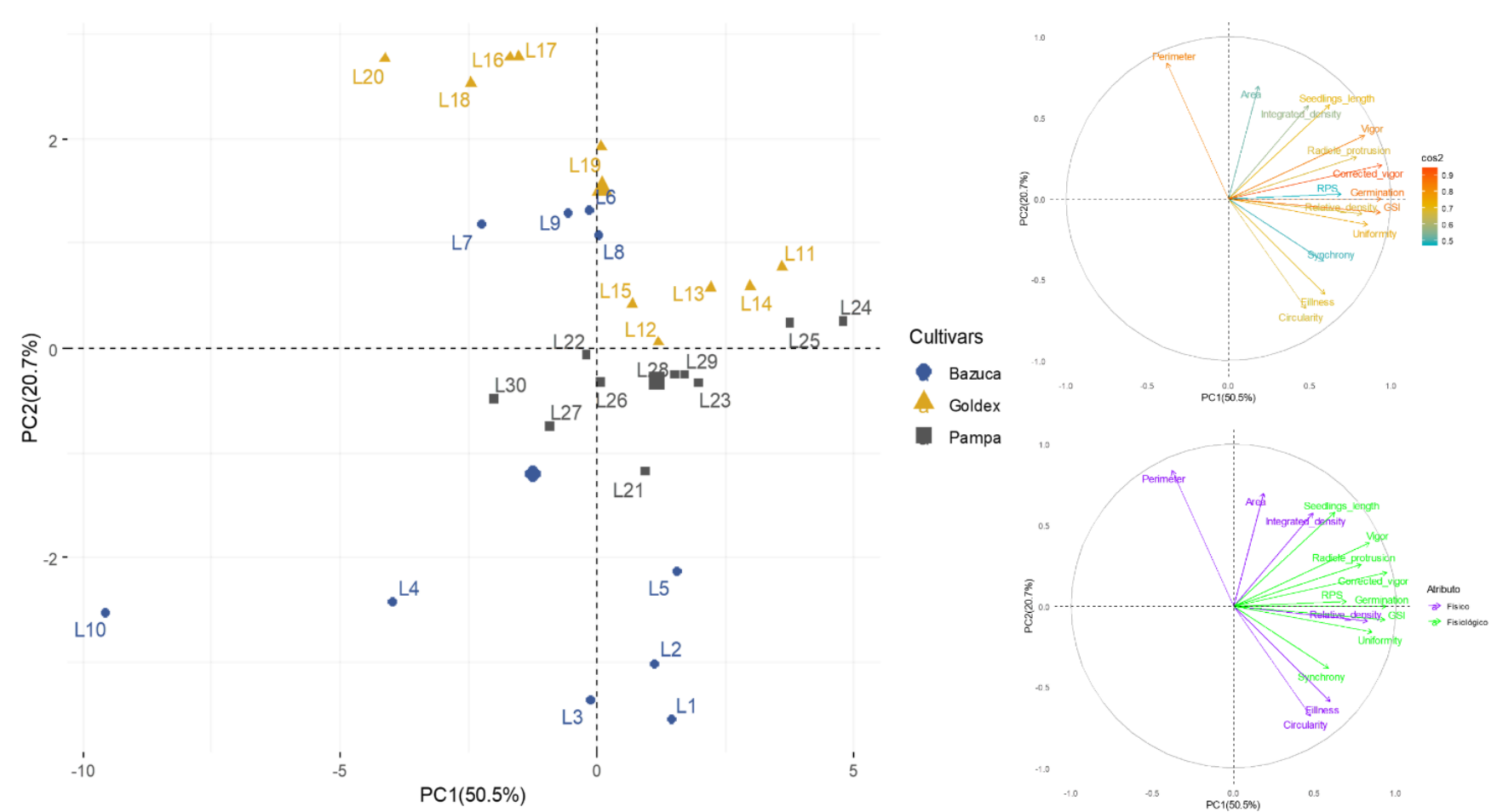

Figure 4. Biplot obtained by the linear combination of the variables related to the physical and physiological characteristics of thirty lots of hybrid melon seeds of three cultivars. 
Moreover, the parameters: relative density, integrated density and filling, obtained from the automated analysis of radiographs of melon seeds, are promising to infer the physiological quality of the seeds and can be recommended for the preliminary evaluation and decision making regarding the disposal of seed lots, optimizing this process and reducing production costs.

\section{CONCLUSIONS}

The automated analysis of radiographic images allows a simple and fast way to obtain reliable information about the physical characteristics of the seeds and to generate parameters related to the physiological quality. The relative and integrated densities were, among the variables obtained from X-ray images, those that stood out to estimate the physiological potential of the seeds.

\section{ACKNOWLEDGEMENTS}

The authors are grateful to the Coordenação de Aperfeiçoamento de Pessoal de Nível Superior (CAPES), Conselho Nacional de Desenvolvimento Científico e Tecnológico (CNPq) and Fundação de Amparo à Pesquisa do Estado de Minas Gerais (FAPEMIG) for the financial support.

\section{REFERENCES}

ABUD, H.F.; CICERO, S.M.; GOMES-JUNIOR, F.G. Radiographic images and relationship of the internal morphology and physiological potential of broccoli seeds. Acta Scientiarum: Agronomy, v.40, n.1, p.1-9, 2018. http://dx.doi.org/10.4025/actasciagron.v40i1.34950

BORGES, S.R.S.; SILVA, P.P.; ARAÚJO, F.S.; SOUZA, F.F.J.; NASCIMENTO, W.M. Tomato seed image analysis during the maturation. Journal of Seed Science, v.41, n.1, p.22-31, 2019. http://dx.doi.org/10.1590/2317-1545v41n1191888

BRASIL. Ministério da Agricultura, Pecuária e Abastecimento. Regras para análise de sementes. Ministério da Agricultura, Pecuária e Abastecimento. Secretaria de Defesa Agropecuária. Brasília: MAPA/ACS, 2009. 395p. http://www.agricultura.gov.br/assuntos/ insumos-agropecuarios/arquivos-publicacoes-insumos/2946_regras_analise_sementes.pdf

FINCH-SAVAGE, W.E.; BASSEL, G.W. Seed vigour and crop establishment: extending performance beyond adaptation. Journal of Experimental Botany, v.67, n.3, p.567-591, 2016. http://dx.doi.org/10.1093/jxb/erv490

GOMES-JUNIOR, F.G.; YAGUSHI, J.T.; BELINI, U.L.; CICERO, S.M.; TOMAZELLO-FILHO, M. X-ray densitometry to assess internal seed morphology and quality. Seed Science and Technology, v.40, n.1, p.102-107, 2012. http://dx.doi.org/10.15258/sst.2012.40.1.11

GOMES-JUNIOR, F.G.; CHIQUITO, A.A.; MARCOS-FILHO, J. Semi-automated assessment of the embryonic area of cucumber seeds and its relationship to germination and seedling length. Journal of Seed Science, v.35, n.2, p.183-189, 2013. http://dx.doi. org/10.1590/S2317-15372013000200007

HUANG, M.; WANG, Q.G.; ZHU, Q.B.; QIN, J.W.; HUANG, G. Review of seed quality and safety tests using optical sensing technologies. Seed Science and Technology, v.43, n.3, p.337-366, 2015. http://dx.doi.org/10.15258/sst.2015.43.3.16

JAVORSKI, M.; CASTAN, D.O.C.; SANTANNA, S.; GOMES-JUNIOR, F.G.; CICERO, S.M. Image analysis to evaluate the physiological potential and morphology of pearl millet seeds. Journal of Seed Science, v.40, n.2, p.127-134, 2018. http://dx.doi.org/10.1590/23171545v40n2176904

KOTWALIWALE, N.; SINGH, K.; KALNE, A.; JHA, S.N.; SETH, N.; KAR, A. X-ray imaging methods for internal quality evaluation of agricultural produce. Journal of Food Science and Technology, v.51, n.1, p.1-15, 2014. http://dx.doi.org/10.1007/s13197-011-0485-y

LEÃO-ARAÚJO, É.F.; GOMES-JUNIOR, F.G.; SILVA, A.R.; PEIXOTO, N.; SOUZA, E.R.B. Evaluation of the desiccation of Campomanesia adamantium seed using radiographic analysis and the relation with physiological potential. Agronomy Journal, v.111, n.2, p.592600, 2019. http://dx.doi.org/10.2134/agronj2018.05.0302

LEGLAND, D.; EL-HAGE, F.; MÉCHIN, V.; REYMOND, M. Histological quantification of maize stem sections from FASGA-stained images. Plant Methods, v.13, n.84, p.1-11, 2017. http://dx.doi.org/10.1186/s13007-017-0225-z 
MAHAJAN, S.; DAS, A.; SARDANA, H.K. Image acquisition techniques for assessment of legume quality. Trends in Food Science and Technology, v.42, n.2, p.116-133, 2015. http://dx.doi.org/10.1016/j.tifs.2015.01.001

MEDEIROS, A.D.; ARAÚJO, J.O.; LEÓN, M.J.Z.; SILVA, L. J.; DIAS, D.C.F.S. Parameters based on X-ray images to assess the physical and physiological quality of Leucaena leucocephala seeds. Ciência e Agrotecnologia, v.42, n.6, p.643-652, 2018. http://dx.doi. org/10.1590/1413-70542018426023318

MEDEIROS, A.D.; SILVA, L.J.; PEREIRA, M.D.; OLIVEIRA, A.M.S.; DIAS, D.C.F.S. High-throughput phenotyping of brachiaria grass seeds using free access tool for analyzing X-ray images. Anais da Academia Brasileira de Ciências, 2019.

MEDEIROS, A.D.; PEREIRA, M.D. SAPL ${ }^{\circledR}$ : a free software for determining the physiological potential in soybean seeds. Pesquisa Agropecuária Tropical, v.48, n.3, p.222-228, 2018. http://dx.doi.org/10.1590/1983-40632018v4852340

MIART, F.; FONTAINE, J.X.; PINEAU, C.; DEMAILLY, H.; THOMASSET, B.; VAN WUYTSWINKEL, O.; PAGEAU, K.; MESNARD, F. MUSeeQ, a novel supervised image analysis tool for the simultaneous phenotyping of the soluble mucilage and seed morphometric parameters. Plant Methods, v.14, n.112, 2018. http://dx.doi.org/10.1186/s13007-018-0377-5

NOGUEIRA-FILHO, F.P.; OLIVEIRA, A.B.; PEREIRA, M.S.; LOPES, M.F.Q.; SILVA, R.T. Efetividade do teste de raios x para avaliação da qualidade fisiológica de sementes de gergelim em função da posição dos frutos na planta. Revista Brasileira de Ciências Agrárias, v.12, n.4, p.435-440, 2017. http://dx.doi.org/10.5039/agraria.v12i4a5474

RAHMAN, A.; CHO, B.K. Assessment of seed quality using non-destructive measurement techniques: a review. Seed Science Research, v.26, n.4, p.285-305, 2016. http://dx.doi.org/10.1017/S0960258516000234

SCHINDELIN, J.; ARGANDA-CARRERAS, I.; FRISE, E.; KAYNIG, V.; LONGAIR, M.; PIETZSCH, T.; PREIBISCH, S.; RUEDEN, C.; SAALFELD, S.; SCHMID, B.; TINEVEZ, J.Y.; WHITE, D.J.; HARTENSTEIN, V.; ELICEIRI, K.; TOMANCAK, P.; CARDONA, A. Fiji: an open-source platform for biological-image analysis. Nature Methods, v.9, p.676-682, 2012. http://dx.doi.org/10.1038/nmeth.2019

SILVA, L.J.; MEDEIROS, A.D.; OLIVEIRA, A.M.S. SeedCalc, a new automated R software tool for germination and seedling length data processing. Journal of Seed Science, v.41, n.2, p.250-257, 2019. http://dx.doi.org/10.1590/2317-1545v42n2217267

SILVA, P.P.; FREITAS, R.A.; CÍCERO, S.M.; MARCOS-FILHO, J.; NASCIMENTO, W.M. Análise de imagens no estudo morfológico e fisiológico de sementes de abóbora. Horticultura Brasileira, v.32, n.2, p.210-214, 2014. http://dx.doi.org/10.1590/S010205362014000200016

SIMAK, M. Testing of forest tree and shrub seeds by X-radiography. In: Tree and Shrub Seed Handbook. Zurich: ISTA, 1991. p.1-28.

TANABATA, T.; SHIBAYA, T.; HORI, K.; EBANA, K.; YANO, M. SmartGrain: high-throughput phenotyping software for measuring seed shape through image analysis. Plant Physiology, v.160, n.4, p.1871-1880, 2012. http://dx.doi.org/10.1104/pp.112.205120

TELLO, J.; MONTEMAYOR, M.I.; FORNECK, A.; IBÁÑEZ, J. A new image-based tool for the high throughput phenotyping of pollen viability: evaluation of inter and intra-cultivar diversity in grapevine. Plant Methods, v.14, n.3, p.1-17, 2018. http://dx.doi. org/10.1186/s13007-017-0267-2

VASSEUR, F.; BRESSON, J.; WANG, G.; SCHWAB, R.; WEIGEL, D. Image-based methods for phenotyping growth dynamics and fitness components in Arabidopsis thaliana. Plant Methods, v.14, n.63, p.1-11, 2018. http://dx.doi.org/10.1186/s13007-018-0331-6 use, distribution, and reproduction in any medium, provided the original work is properly cited. 